\title{
NANOBACTERIA-LIKE PARTICLES: A THREAT TO CELL CULTURES
}

\author{
Amauri Braga Simonetti ${ }^{1 *}$, Gelsa Edith Englert ${ }^{2}$; Karen Campos $^{1}$; Michelle Mergener ${ }^{1}$; Cíntia de David ${ }^{1}$; \\ Anna Paula de Oliveira ${ }^{1}$; Paulo Michel Roehe ${ }^{1,3}$
}

\begin{abstract}
${ }^{1}$ Departamento de Microbiologia, Instituto de Ciências Básicas da Saúde, Universidade Federal do Rio Grande do Sul, Av. Sarmento Leite 500, Porto Alegre, RS 90050-170, Brazil; ${ }^{2}$ Escola de Engenharia-Departamento de Metalurgia-Centro de Tecnologia, Av. Sarmento Leite 500, Porto Alegre, RS 90050-170, Brazil; ${ }^{3}$ Instituto de Pesquisas Veterinárias Desidério FinamorIPVDF-FEPAGRO Saúde Animal, Cx Postal 47, Eldorado do Sul, RS 92990-000, Brazil.
\end{abstract}

Submitted: January 03, 2006; Returned to authors for corrections: March 30, 2006; Approved: July 18, 2006

\begin{abstract}
The main goal of this study is to alert researchers who work with cell cultures for the risk of contamination by structures called nanobacteria (NB). NB are tiny structures with size varying from 80 to $500 \mathrm{~nm}$, commonly occurring in clusters and producing a biofilm which contains carbonate or hydroxyl apatite. The most likely source of cell culture contamination by such organisms is serum used as supplement in culture media. The presence of NB leads to a progressive culture deterioration with accumulation of granules (probably phagocytized NB) in cytoplasmic vacuoles, an increasing number of dead cells in the supernatant and degeneration of cells that remained attached to the bottom of the vessel. NB can also be found in culture supernatants where they are found in clusters with variable size and displaying brownian movement. In this study, 19 cell lineages, 8 batches of sera and 1 batch of growth supplement from different sources were analyzed. Samples from sera were cultured in Eagle's Minimum Essential Medium (E-MEM) or incubated directly at $37^{\circ} \mathrm{C}$. Tests carried out to detect the presence of extracellular bacteria, Mycoplasma sp and viruses were all negative. Analysis by scanning electron microscopy (SEM) revealed tiny oval structures less than $500 \mathrm{~nm}$ in size, isolated or in small groups, in all material analyzed except in one fetal bovine serum batch.
\end{abstract}

Key words: nanobacteria, cell culture, fetal bovine serum (FBS), contamination

\section{INTRODUCTION}

Progress in biological research is intimately linked to the possibility of in vitro cell culture manipulations, particularly in virology, which is the main area of interest in our laboratory. However, cell culture contaminants are a serious problem, since they can undermine experiments. Bacteria, virus and fungi can easily invade cell cultures if aseptic techniques are not used. However, fastidious organisms growing slowly without producing gross changes in the medium are a serious problem, because they are not easily detected $(10,24)$.

Recent publications reported contamination of fetal bovine serum and cell cultures by structures named nanobacteria (NB) $(1,5,19)$. NB are organisms raging from 80 to $500 \mathrm{~nm}$ in size, thus passing through $450 \mathrm{~nm}$ filters commonly used for media clarification, and even "sterilizing" filters (that is, $200 \mathrm{~nm}$ filters). These organisms are covered by an apatite shelter and can be observed either isolate as individual particles or in small groups or clumps. NB are slow growing, not culturable in any standard microbiological medium, not Gram stainable and resistant to heat and most antibiotics routinely used in cell culture $(1,5,15,16,19,20)$. Due to its capacity to produce apatite it has been postulated that NB could be associated with extraskeletal calcification and might represent an infectious origin for human renal stones $(3,4,8,14,15,17,23)$.

In this study we report the efforts in our laboratory to investigate cell culture deterioration, where nanobacteria-like particles (NBLP) represented the main contaminants.

*Corresponding Author. Mailing address: Dep. de Microbiologia Instituto de Ciências Básicas da Saúde - Universidade Federal do Rio Grande do Sul Av. Sarnento Leite, 500 - Cep: 90050-170. Porto Alegre, RS - Brasil. Tel.: (51) 3316-4111 ou (51) 3316-4111. E-mail: rejadel@yahoo.com.br 


\section{MATERIALS AND METHODS}

\section{Cell cultures}

Nineteen cell lineages were examined in this study (Table 1). Cells were cultured in $75 \mathrm{~cm}^{2}$ flasks (NUNC) containing Eagle's Minimal Essential Medium (E-MEM, Gibco-BRL, Long Island, New York, USA) supplemented with $10 \%$ fetal bovine serum and $0.001 \%$ enrofloxacin (Baytril, Bayer, São Paulo, SP), incubated in $5 \% \mathrm{CO}_{2}-95 \%$ air at $37^{\circ} \mathrm{C}$. Cells were trypsinized (0.05\% trypsine lot no. 6AK4170, Gibco-BRL, Long Island, New York, USA) and subcultured at every 3 to 5 days.

\section{Sera}

One milliliter aliquots from 8 batches of sera and 1 growth supplement from different suppliers were added to $25 \mathrm{~cm}^{2}$ flasks containing 9 milliliters of E-MEM (Gibco-BRL, Long Island, New York, USA) and incubated at $37^{\circ} \mathrm{C}$ for up to 12 weeks. Culture media alone, i.e. serum free E-MEM, incubated under the same conditions were used as controls. Materials used as culture supplement included in this study are listed in Table 2. In addition, $2 \mathrm{ml}$ of each batch under testing were incubated at $37^{\circ} \mathrm{C}$, without addition of E-MEM, for up to 12 weeks.

Table 1. Cell lineages examined in this study.

\begin{tabular}{ll}
\hline \multicolumn{1}{c}{ Cell lineages } & \multicolumn{1}{c}{ Suppliers } \\
\hline BHK-BAYER & Laboratório Bayer Porto Alegre, RS, Brazil \\
BT & Central Veterinary Agency, Surrey, UK \\
CER & Central Veterinary Agency, Surrey, UK \\
CRFK & Central Veterinary Agency, Surrey, UK \\
EBTR & Holanda (Lelystad) \\
HEP-2 & Centro de Biotecnologia - UFRGS, Porto Alegre, RS, Brazil \\
MDBK (ATCC22) & Faculdade Veterinária-UFSM, Santa Maria, RS, Brazil \\
MDCK & Instituto Adolfo Lutz-São Paulo, SP, Brazil \\
MDCK & Laboratório Virologia Animal-Centro Ciências Agrárias, UEL, PR, Brazil \\
MMTV & Primary culture of cells from a murine mammary tumour(prepared in our laboratory) \\
$\mathrm{N}_{2} \mathrm{~A}$ & Central Veterinary Agency, Surrey, UK \\
$\mathrm{NS}$ & Central Veterinary Agency, Surrey, UK \\
$\mathrm{PK}_{15}$ & ATCC \\
$\mathrm{PK}_{15}$ & Faculdade Veterinária-UFSM, Santa Maria, RS, Brazil \\
$\mathrm{RK}_{13}$ & Tübingen, Germany \\
$\mathrm{SK}_{6}$ & Central Veterinary Agency, Surrey, UK \\
$\mathrm{SP}_{2} \mathrm{O}$ & Central Veterinary Agency, Surrey, UK \\
$\mathrm{TT}_{\text {VERO }}$ & Primary calf testis (prepared in our laboratory) \\
$\mathrm{V}$ & Central Veterinary Agency, Surrey, UK \\
\hline
\end{tabular}

Table 2. Materials used as culture supplements analysed in this study.

\begin{tabular}{ll}
\hline \multicolumn{1}{c}{ Materials } & \multicolumn{1}{c}{ Suppliers } \\
\hline AMNIOMAX-C100 Lot no.1107512 & GIBCO-BRL, New York, USA \\
FBS Lot no. 004/00 & CULTILAB, Campinas, SP, Brasil \\
FBS Lot no. 013/04 & CULTILAB, Campinas, SP, Brasil \\
FBS Lot no. 014/04 & CULTILAB, Campinas, SP, Brasil \\
FBS Lot no. 40F6245K & Gibco-BRL, Long Island, New York, USA \\
FBS Lot no.40G3329K & Gibco-BRL, Long Island, New York, USA \\
Equine serum & Fac. Veterinária-UFSM, Santa Maria, RS, Brasil \\
Calf serum- pool & IPVDF, Eldorado do Sul, RS, Brasil \\
Bovine serum pool inactivaded with binary ethylenimine & Líder Laboratory, Porto Alegre, RS, Brasil \\
\hline
\end{tabular}

FBS : fetal bovine serum. 


\section{Microbiological examination}

To investigate the presence of common bacterial contaminants, samples of trypsinized cells and serum were examined by Gram stain and cultured in brain-heart infusion broth (BHI, Difco-Interlab, São Paulo, SP) for 8 to 12 weeks at $37^{\circ} \mathrm{C}$. Mycoplasma sp were investigated using Hayflick modified medium (21) and urea-arginine broth (Mycoplasma IST BioMérieux, Lyon< France). Contamination by bovine parainfluenzavirus type 3 (BPI-3) was checked by culture and confirmed by RT-PCR; presence of bovine herpesviruses types 1 and 5 was examined by looking for the presence of cytopathic effect on cell cultures. Non-cytopathic BVDV was investigated by an immunoperoxidase assay as described elsewhere (31).

\section{Scanning electron microscopy}

Material from cell cultures and sera were analyzed by scanning electron microscopy (SEM). Five milliliters of trypsinized cells or serum were centrifuged (Sigma 2K15) at $10,000 \times \mathrm{g}$ for 15 minutes, the supernatant discarded and the remaining pellet washed 3 times with PBS $(116 \mathrm{mM} \mathrm{NaCl}, 20.8$ $\mathrm{mM} \mathrm{Na}_{2} \mathrm{HPO}_{4}, 2.9 \mathrm{mM} \mathrm{KH}_{2} \mathrm{HPO}_{4}$, $\mathrm{pH}$ 7.4). After resuspension in a small volume of PBS, cells were transferred to coverslips, allowed to dry at room temperature and fixed with $1.25 \%$ glutaraldehyde (Merck) in 0.5 M PBS containing 4\% sucrose for 16 hours at $4^{\circ} \mathrm{C}$. After extensive washings in PBS, specimens were dehydrated in ascendent concentrations of ethanol (50, $70,70,90$ and $100 \%$ ) at room temperature for 40 minutes each solution. After treated with acetone (Merck) for 20 minutes and allowed to dry at room temperature the coverslips were coated with a 20 - $40 \mathrm{~nm}$ gold layer (Sputtering-Balzers Union ScD040, Balzers, Lichtenstein) before being examined with scanning electron microscope (Philips E.M. 301).

\section{RESULTS}

All 19 cell lineages analyzed after 1 to 4 weeks culture time showed a progressive deterioration. Microscopy revealed the presence of extra and intracellular particles (granulations), an increasing number of dead cells and degeneration of cells that remained attached to the bottom of the vessel. These particles could also be seen in culture supernatants, many were in clumps varying in size and displaying brownian movement. Fig. 1A shows an image of MDBK cells with NBLP clusters after 4 weeks of incubation at $37^{\circ} \mathrm{C}$. After 8 weeks, 8 out of $9(89 \%)$ batches of material used as supplement incubated at $37^{\circ} \mathrm{C}$ without E-MEM addition were opalescent (Fig. 1B) and displayed a white-colored sediment after 12 weeks of incubation (Fig. 1C). The exception was fetal bovine serum lot no.40F6245K, Gibco, where no alteration was observed after incubation. With E-MEM addition the same material presented a similar aspect after 12 weeks of incubation but this aspect was not observed in serum free EMEM controls (results not shown). Methods used in this study failed to detect any bacterial or virus contamination in any of the samples analyzed.

SEM of contaminated cell cultures revealed structures with variable sizes, smaller than $500 \mathrm{~nm}$, spherical or ovoid, either isolated or in clusters (Fig. 2A). Similar structures were observed in FBS samples directly examined by SEM (Fig. 2B) or after eight-week incubation in E-MEM (Fig. $2 \mathrm{C}$ ) at $37^{\circ} \mathrm{C}$.

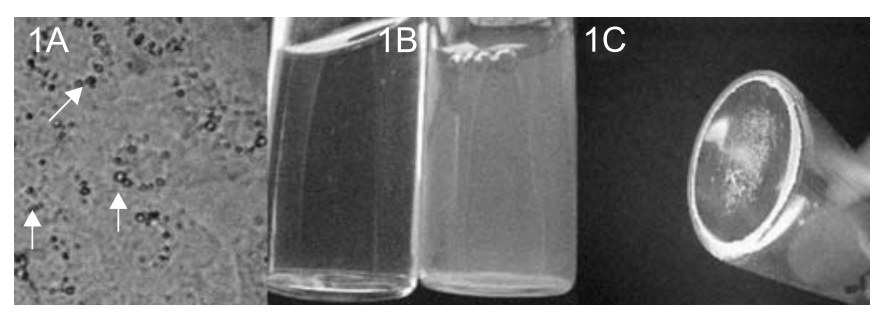

Figure 1. Images of contaminated material after incubation at $37^{\circ} \mathrm{C}$. A) Cell culture after 4 weeks of incubation (400x). B) Fetal bovine serum: tube on the left, before incubation; tube on the right, after eight-week incubation. C) Fetal bovine serum: white-colored sediment after twelve-week incubation. Arrows indicate NBLP.

\section{DISCUSSION}

For years we have been facing difficulties with cultures in our virology laboratory due to cell alterations after a few weeks' incubation. When analyzed at the optical microscope we observed the presence of particles with variable size, usually in clusters and apparently attached to cells (Fig. 1A). It was also possible to visualize these structures in cytoplasmic vacuoles as well as in cell culture supernatants where they presented brownian movement. Samples taken from these contaminated cell cultures were tested by standard methods with negative results for viruses, bacteria and Mycoplasma sp growth.

Searching in the literature for possible causes of cell culture contamination we found a report describing contamination of long-term cell cultures by bacteria-like particles (1). According to those authors, the initial clue to the nature of the problem was the fortuitous culturing of the same cells in two media which differed only in their serum supplement. In the presence of one serum batch, which contained the particles, the mammalian cells died within four weeks. They also observed that the particles produced a biofilm containing carbonate or hydroxyl apatite and multiplied similarly whether mammalian cells were present or not. After extensive microscopic, biochemical and molecular studies, those authors concluded that these structures were bacteria belonging to the alfa-2 subgroup of Proteobacteria and were named nanobacteria 

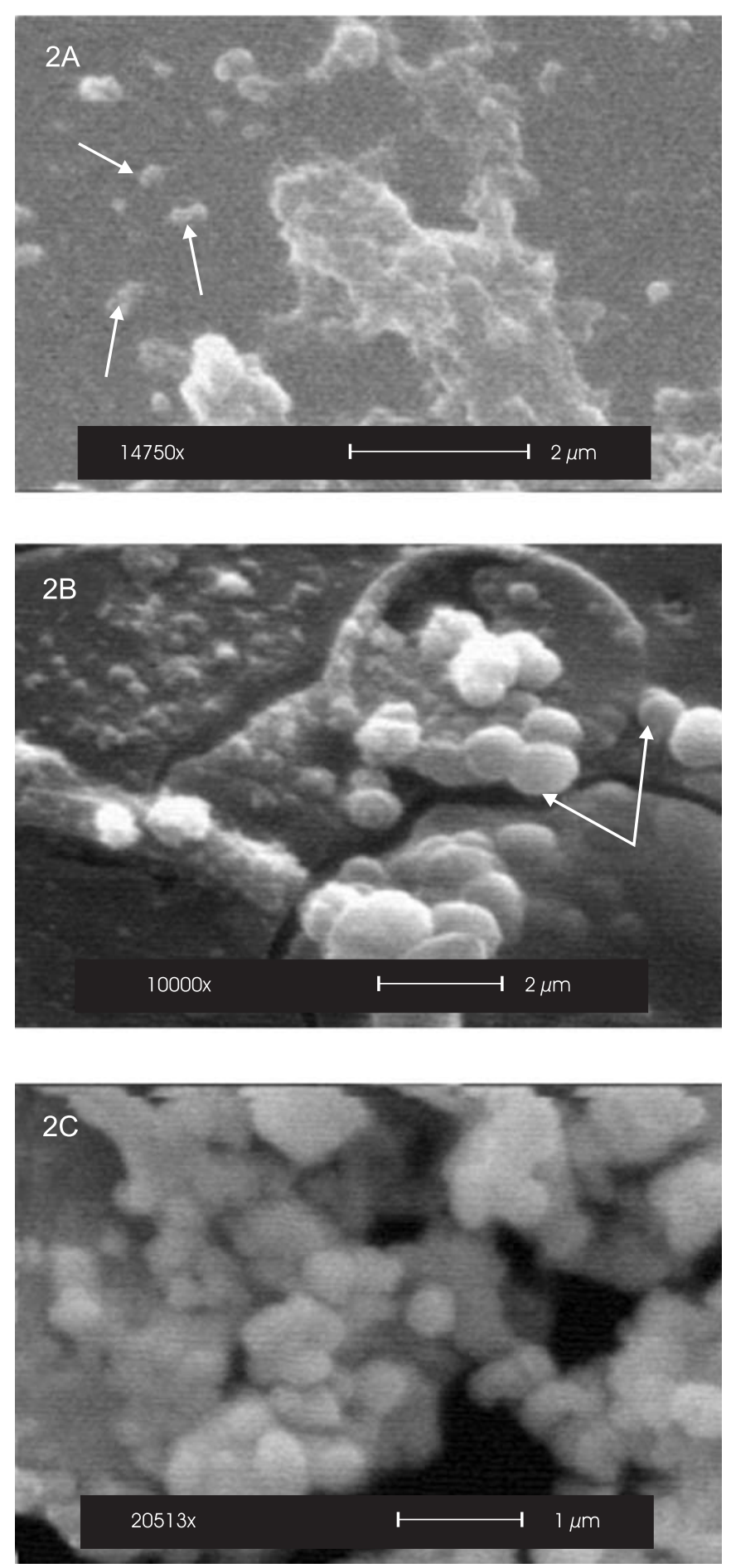

Figure 2. SEM images of material from contaminated cell culture and fetal bovine sera. A) MDBK cell culture after four-week incubation at $37^{\circ} \mathrm{C}$ (bar $\left.2 \mu \mathrm{m}, 15000 \mathrm{X}\right)$. B) Fetal bovine serum directly examined (bar $2 \mu \mathrm{m}, 10000 \mathrm{X}$ ). C) Fetal bovine serum culture in E-MEM after eight-week incubation (bar $1 \mu \mathrm{m}$, 20500X). Arrows indicate NBLP.
(NB) $(16,20)$. Further studies carried out by the same group investigated the interaction of NB with cultured mammalian cells, showing NB internalization and cytotoxicity in 3T6 fibroblasts used as a model $(5,15)$. These results were obtained by optical and electron microscopy, and indirect immunofluorescence staining using specific monoclonal antibodies. Taking into consideration these findings from the literature we decided to examine the cell lineages and sera available in the laboratory by SEM. Tiny coccoid structures (less than $500 \mathrm{~nm}$ ), alone or in clusters, were visualized in cell culture specimens (Fig. 2A) and sera (Fig. 2B), with the exception of one serum batch. Due to the great similarity in size and shape with nanobacteria, identified by Kajander and Ciftcioglu (15), these structures were referred to as nanobacteria-like particles (NBLP) in our study.

We then cultured material used as growth supplement and most $(89 \%)$ batches were opalescent at the naked eye. These samples were subsequently analyzed by SEM and contained NBLP (Fig. 2C). Kajander et al. $(19,20)$ reported the presence of NB in more than $80 \%$ of 50 FBS commercial batches analyzed. These results are important because they show these particles directly in sera used as supplement, which has implications in terms of culture contamination all over the world. As it occurred with these authors the main problem for us was the presence of these structures in long-term experiments when they were present in high concentrations in relation to cells. However, it was not possible to know if contaminations of cell cultures in our laboratory were due to a previous cell contamination or due to the contaminated serum batches used as supplement.

It has been mentioned that NB might be a serious threat in preparation of products for human use, for example contamination of vaccines prepared with viral antigens produced from cell culture supplemented with FBS (7). It was reported recently the presence of NB in viral vaccines (17).

An interesting aspect of NB is their capacity of biomineralization by producing biofilm and mineral aggregates (20). In our study we also visualized a kind of mineralized biofilm on the bottom of culture flasks and tubes after incubation (Fig. 1C). Through chemical analysis and energydispersive x-ray microanalysis (EDX) Kajander and Ciftcioglu (15) observed that in all stages of development NB produced biogenic apatite, same material found in most tissues where calcification occurs. In the same study the authors demonstrated, by TEM, the presence of a thick layer that revealed an high content of carbonate apatite when analyzed by Fourier Transform IR Spectroscopy (FTIR). Due to these NB properties, studies have been carried out in different human materials to associate $\mathrm{NB}$ and chronic diseases involving calcification $(3,4,15,22,23,27,30,32)$.

In spite of the possibility of NB being etiological agents of extracellular calcification there is still controversy on the nature 
Nanobacteria-like particles

of NB and their role on biomineralization. Major criticism is in relation to their small size, 10 to 100 times less than that of common bacteria, not sufficient for a living cell to contain all macromolecular components $(25,28,29)$. Different authors question the existence of nucleic acids and NB capacity of biomineralization, pointing out that this process can be initiated by nonliving macromolecules and apatite itself (9). Although the structures (NBLP) observed in our study were morphologically similar to NB we can not state that they are living organisms, unless proved by nucleic acids existence. The importance of our findings is that these structures are reproducible and its presence really disturbs the cell culture growth.

If these structures called nanobacteria are truly living organisms, then their significance is far reaching and profound. NB may be mediating many processes currently assumed to be controlled by inorganic chemical reactions and may also be controlling processes such as extraskeletal calcification. Furthermore, they have been detected in bovine, rabbit and human blood which may have implications in basic research, the quality of biotecnological products and human disease $(20,32)$.

Similar structures to NB have been found in materials from soil and natural water by Folk. Using SEM he has visualized tiny 25 to $200 \mathrm{~nm}$ scale spheroidal and ovoid shaped objects in carbonate sediments and rocks and, because of the general resemblance between these structures and cocci, he named them as "nannobacteria" $(11,12)$. In Brazil, one publication on nanobacteria-like particles was reported so far where the authors investigated their presence in banded iron formations by SEM (2). Interestingly, the discovery of nannobacterial textures in the Martian Meteorite ALH84001 (26), the Allende meteorite and the Murchison meteorite (13) have raised the possibility that nanofossils are precursors of extraterrestrial life.

Experiments are underway in our laboratory to better characterize these structures including biochemical, immunological and molecular methodology.

In conclusion, our results indicated the presence of structures named NBLP in all materials analyzed, except in one FBS batch, with size and morphology very similar to those of NB described in the literature. Whether NB or NBLP are truly microorganisms is still controversial but they represent a potential risk for cell culture contamination and further investigation is required to elucidate this intriguing possibility.

\section{ACKNOWLEDGEMENTS}

We wish to express our gratitude to Dr. Amauri Alfieri and Luciene Giordano from Laboratório de Virologia Animal, Centro de Ciências Agrárias da Universidade Federal de Londrina, Paraná, for Mycoplasma testing. To CNPq and CAPES for financial support.

\section{RESUMO}

\section{Partículas semelhantes à nanobactérias: uma ameaça às culturas de células}

O principal objetivo deste estudo é alertar aos pesquisadores que trabalham com cultivos celulares sobre o risco de contaminação por estruturas denominadas nanobactérias (NB). NB são estruturas muito pequenas cujo tamanho varia de 80 a $500 \mathrm{~nm}$ e que comumente ocorrem em agrupamentos, produzindo biofilme de carbonato ou hidroxiapatita. A fonte mais provável de contaminação dos cultivos celulares por tais organismos é o soro utilizado como suplemento nos meios de cultura. A presença de NB leva a uma progressiva deterioração do cultivo com acúmulo de grânulos (provavelmente NB fagocitadas) em vacúolos citoplasmáticos, um número cada vez maior de células mortas no sobrenadante e degeneração das células que permaneceram aderidas à superfície do frasco de cultura. NB podem ser encontradas também em sobrenadantes de cultivos onde são observadas em agrupamentos de tamanho variável com movimento browniano. Neste estudo, 19 linhagens celulares, 8 lotes de soro e 1 lote de suplemento de diferentes procedências foram analisados. Amostras de soros foram cultivadas em Meio Essencial Mínimo de Eagle (E-MEM) ou incubados diretamente a $37^{\circ} \mathrm{C}$. Testes efetuados para detectar a presença de bactérias extracelulares, Mycoplasma sp e vírus foram todos negativos. Análise por microscopia eletrônica de varredura (SEM) revelou minúsculas estruturas ovóides com tamanho inferior a $500 \mathrm{~nm}$, isoladas ou em pequenos agrupamentos, em todos os materiais analisados exceto em um lote de soro fetal bovino.

Palavras-chave: nanobactéria, cultivo celular, soro fetal bovino (FBS), contaminação

\section{REFERENCES}

1. Akerman, K.K.; Kurone, I.; Kajander, E.O. (1993). Scanning Electron Microscopy of Nanobacteria - Novel Biofilm producing Organisms in Blood. Scanning 15 (Suppl. III), 90-91.

2. Ávila, J.N.; Takehara, L.; Chemale Jr.; F.; Mallmann, G. (2001) Investigation of "Nanobacteria" in banded iron formations by scanning electron microscopy: an example from Urucum and Carajás, Brazil. Acta Microscopica, Suppl. A - XVIII Congress of the Brazilian Society for Microscopy and Microanalysis.

3. Carson, D.A. (1998). An infectious origin of extraskeletal calcification. Proc. Natl. Acad. Sci. USA, 95(14), 7846-7847.

4. Ciftcioglu, N.; Bjorklund, M.; Kuorikoski, K.; Kajander, E.O. (1999). Nanobacteria: an infectious cause for kidney stone formation. Kidney Int., 56(5), 1893-1898.

5. Ciftcioglu, N.; Kajander, E.O. (1998). Interaction of nanobacteria with cultured mammalian cells. Pathophysiology, 4, 259-270.

6. Ciftcioglu, N.; Kajander, E.O. (2001). American Society for Microbiology 101st General Meeting, May 20-24.

7. Ciftcioglu, N.; Kuronen, I.; Akerman, K.; Hiltunen, E.; Laukkanen, J.; Kajander, E.O. (1997). A new potential threat in antigen and antibody products: Nanobacteria. Vaccines, 97, 99-103. 
8. Ciftcioglu, N.; Haddad, R.S.; Golden, D.C.; Morrison, D.R.; McKay, D.S. (2005). A potential cause for kidney stone formation during space flights: enhanced growth of nanobacteria in microgravity. Kidney Int., 67(2), 483-91.

9. Cisar, J.O.; Xu, D.Q.; Thompson, J.; Swaim, W.; Hu, L.; Kopecko, D.J. (2000). An alternative interpretation of nanobacteria-induced biomineralization. Proc. Natl. Acad. Sci. USA, 97(21), 11511-5.

10. Coriell, L.L. (1973). Methods of prevention of bacterial, fungal, and other contaminations, in: J. Fogh (Ed.), Contamination of Tissue Culture, Academic Press, N. York, pp. 29-47.

11. Folk, R.L. (1993). SEM imaging of bacteria and nannobacteria in carbonate sediments and rocks. J. Sed. Petrol., 63, 990-999, 1993.

12. Folk, R.L. (1994). Interaction between bacteria, nannobacteria, and mineral precipitation in hot springs of central Italy. Géog. Phys. Quatern., 48, 233-246.

13. Folk, R.L.; Lynch, F.L.; Mendenhall, J. (1998). Nannobacteria-like carbon bodies in the Allende and Murchison carbonaceous chondrite meterorites, with comparisons to Earth. Geological Society of America Abstracts with Programs, v. 30, pp. a-290.

14. Hjelle, J.T.; Miller-Hjelle, M.A.; Poxton, I.R.; Kajander, E.O.; Ciftcioglu, N.; Jones, M.L.; Caughey, R.C.; Brown, R.; Millikin, P.D.; Darras, F.S. (2000). Endotoxin and nanobacteria in polycystic kidney disease. Kidney Int., 57(6), 2360-2374.

15. Kajander, E.O.; Ciftcioglu, N. (1998). Nanobacteria: An alternative mechanism for pathogenic intra- and extracellular calcification and stone formation. Proc. Natl. Acad. Sci. USA, 95(14), 8274-8279.

16. Kajander, E.O.; Tahvanainen, E.; Kuronen, I.; Ciftcioglu, N. (1994). Comparison of Staphylococci and novel bacteria-like particles from blood. Zbl. Bakt. Suppl. 26, 147-149.

17. Kajander, E.O.; Ciftcioglu, N.; Aho, K. Detection of Nanobacteria in Viral Vaccines. Proceedings of the Am. Soc. Microbiol. 101 General Meeting; 20-24 May 2001; Orlando: abstract Y-3, p.736.

18. Kajander, E.O.; Ciftcioglu, N.; Miller-Hjelle, M.A.; Hjelle, J.T. (2001). Nanobacteria: controversial pathogens in nephrolithiasis and polycystic kidney disease. Curr. Opin. Nephrol. Hypertens, 10(3), 445-452.

19. Kajander, E.O.; Kuronen, I.; Ciftcioglu, N. (1996). Fatal (fetal) bovine serum: discovery of Nanobacteria. Mol. Biol. Cell., 7 (Suppl.), 517.

20. Kajander, E.O.; Kuronen, I.; Akerman, K.K.; Pelttari, A.; Ciftcioglu, N. (1997). Nanobacteria from blood, the smallest culturable autonomously replicating agent on Earth. Proc. SPIE 3111, 420428.

21. Kotani, H.; Butler, G.H.; Tallarida, D.; Cody, C.; McGarrity, G.J. (1990). Microbiological cultivation of Mycoplasma hyorhinis from cell cultures. In vitro Cell. Dev. Biol., 26, 91-96.

22. Kramer, G.; Kingler, H.C.; Steiner, G.E. (2000). Role of bacteria in the development of kidney stones. Curr. Opin. Urol., 10(1), 35-38.

23. Khullar, M.; Sharma, S.K.; Singh, S.K.; Bajwa, P.; Sheikh, F.A.; Relan, V.; Sharma, M. (2004). Morphological and immunological characteristics of nanobacteria from human renal stones of a north Indian population. Urol Res., 32(3), 190-5.

24. Lincoln, C.K.; Gabridge, M.G. (1998). Cell culture contamination: sources, consequences, prevention, and elimination. Methods Cell Biol., 57, 49-65.

25. Maniloff, J. (1997). Nannobacteria: size limits and evidence. Science, 276 (5320), 1773e.

26. McKay, D.S.; Gibson, E.K.; Thomas-Keprta, K.L.; Vali, L.H.; Romanek, C.S.; Clemett, S.J.; Chillier, Z.D.F.; Maechling, C.R.; Zare, R.N. (1996). Search for past life on Mars: possible relic biogenic activity in Martina meteorite ALH84001. Science, 273, 924.

27. Miller V.M.; Rodgers G.; Charlesworth J.A.A.; Kirkland B.; Severson S.R.; Rasmussen T.E.; Yagubyan M.; Rodgers J.C.; Cockerill F.R.; Folk R.L.; Rzewuska-Lech E.; Kumar V.; Farell-Baril G.; Lieske J.C. (2004). Evidence of nanobacterial-like structures in calcified human arteries and cardiac valves. Am J Physiol Heart Circ. Physiol., 287(3),H1115-24.

28. Nealson, K.H. (1997). Nannobacteria : size limits and evidence. Science, 276 (5320), 1773e.

29. Psenner, R.; Loferer, J. (1997). Nannobacteria: size limits and evidence. Science, 276 (5320), 1773e.

30. Puskas, L.G.; Tiszlavicz, L.; Razga, Z.; Torday, L.L.; Krenacs, T.; Papp, J.G. (2005). Detection of nanobacteria-like particles in human atherosclerotic plaques. Acta Biol. Hung., 56(3-4), 233-45.

31. Saunders G.C. (1977). Development and evaluation of an enzymelabeled antibody test for rapid detection of hog cholera antibodies. Am. J. Vet. Res., 38(1), 21-25.

32. Wen, Y.; Li, Y.G.; Yang, Z.L.; Wang, X.J.; Wei, H.; Liu, W.; Miao, X.Y.; Wang, Q.W.; Huang S.F.; Yang J.; Kajander E.O.; Ciftcioglu N. (2005). Detection of nanobacteria in serum, bile and gallbladder mucosa of patients with cholecystolithiasis. Chin. Med. J., (Engl) 118(5), 421-4. 